\title{
Elite and Mass Appeal of Roman Imperial Female Portraiture: the Case of Vibia Sabina
}

\begin{abstract}
Sabina's portraiture has been characterized by her mature type that evokes the ideal adornment of Hellenic goddesses. Yet her earlier heads show experimentation with coiffures also depicted on private portraits. One portrait head, in particular, represents Sabina with a hybrid coiffure, combining elements of a period style with those connoting Venus. The process of development of portrait types, and their relationship to private portraits, may be delineated through a study of such lesser-known works.
\end{abstract}

Scholarship of the portraiture of the Roman imperial women is at a crossroads. Their imagery was seen to dominate as members of the imperial court and then citizens followed their lead by imitating their looks. Changes in style or adornment were attributed to fashion followed most scrupulously by those in the upper social tiers and gradually trickled down below. In the more extreme versions of this theory, all portraits are imprinted with some features of the imperial portrait. More recently, however, scholars have questioned this perspective. In some periods of the high empire, marble heads are often difficult to identify, and the female imperial portraits are not easily distinguished from the portraits of private citizens (that is, those not depicting the imperial family). ${ }^{1}$ This occurs despite the fact that we have labeled images, portrait profiles, on coins to aid us in recognizing the imperial subjects. That imperial women in these times appear less individualized has been attributed to the prevailing code of feminine modesty by which the emperors' wives also must recede from public view-or, rather, be cloaked by generic representations, conventional types with a wide currency. Other scholars attribute the less distinctive imagery of imperial women to a bottoms-up phenomenon in which motifs were popularized by matrons of lesser rank, perhaps even of the middling levels of society. ${ }^{2}$ In this scenario, the appeal of tradition rather than flux of the fashionable world played a greater role. In some periods the sheer diversity of styles and adornment blunt the effect of the imperial image and lessen its influence. In others, the dominant look turns to the Hellenizing model of the

1. Fejfer 2008, 340, 344, 353-55.
2. Fejfer 2008, 356, questions the trend-setting role of the empress; D'Ambra 2013, 524, on traditional aspects of the Flavian toupet. 
goddess, whose youthful beauty and grace provided an inspirational model for mortal women. In other words, portraits of imperial women in the period of the high empire do not seem to be clearly nor consistently distinct from the portraiture of the women of Rome. ${ }^{3}$

Clearly the portraits of the imperial women function differently than those of the emperor with his readily recognizable physiognomy and sculptural style that influenced the production of marble heads of the elite and citizenry beneath him. Female statue types used in portrait sculpture did not change for long periods (centuries) and, more importantly, did not depict "real" subjects; instead, they were mythological: personifications or goddesses. ${ }^{4}$ Imperial women of the late first and second centuries did not participate in political life in any official, regular, or even ancillary manner - and the traditional role of leading women in religion seemed diminished. ${ }^{5}$ Thus the statuary bodies, in passive poses of display, endowed the emperor's female kin with desirable attributes or honorable virtues, often abstract concepts or broad conceits. Due to these requirements of the genre, the portrait of the empress in the high empire was less individualized and more generic by its very nature.

The images of Vibia Sabina, wife of Hadrian, are curious in this regard because they depart from the styles and standards established by the imperial women preceding her. ${ }^{6}$ Although any changes in style or adornment have been attributed to fashion, Sabina's portraits turn away from the high-piled, architectonic coiffures of the Flavian and Trajanic women to evoke the simplicity and grace of a Hellenic goddess. This is most apparent in the hair swept back in a central part and the relative agelessness of Sabina. Her sculpted image reverts to the timeless ideal of the goddess and maintains that look. The explanation for this is found in Hadrian's Philhellenism, his allegedly scholarly revival of the Greek past. Yet, every empress was assimilated to goddesses in image, and the ideal Hellenic type served as a default mode throughout the empire. Sabina's portraits may represent something else.

Most importantly, Sabina's portraits were not emulated by the women of Rome or elsewhere. ${ }^{7}$ Most private portraits continued to be adorned with the complex, upholstered coiffures made popular in the Trajanic period. The image of the leading imperial women seemed to have little or no effect on those who should have looked up to her for inspiration. Although recent scholarship has modified this top-down scenario, one current view maintains that the imperial female portrait bears a close relationship to the images of women of lesser rank. For ex., the Flavian toupet coiffure, associated with Julia Titi and Domitia, appears on many portraits of unidentified women. The private portraits are thought to date after those of the Flavian imperial women, although it is more likely that the young women of the late Flavian dynasty wore the hairstyle already popularized by elite women (recall that the wife and daughter of Vespasian died before he became emperor, and the wives of Titus, who did not remain married to him when he came into power, are poorly documented). ${ }^{8}$ The Flavian women's images conform to those of their cohort. In contrast, Sabina's mature look stands in isolation-literally alone and above that of the women of

3. Fejfer 2008,356 and 368 , makes the case for the study of imagery of imperial women alongside of the portraiture of Roman women.

4. Fejfer 2008, 341.

5. Boatwright 1991, 532-40.

6. Fittschen-Zanker 1983, 10-12, n. 10; Buccino 2011, 373; Buccino 2012, 271.

7. Fejfer, 352-53.

8. D’Ambra 2013, 511-25. 
Rome. In the mid-second century CE, it seemed that the emperor's wife neither served as a model nor mirror to matrons and maidens.

Sabina proves a difficult subject to approach. Like most imperial women of the high empire, she remains in the shadows. The facts of her biography are few: as Trajan's grandniece, she married Hadrian in $100 \mathrm{CE}$, coins honor her with the title Augusta during Hadrian's reign (perhaps after 119 or in 128 - the chronology is not clear), and then she died in 136 or 137 when she was in her fifties. ${ }^{9}$ In the ancient historical sources, she has been cast as an unhappy or disappointed woman with a "harsh" and "irritable" personality (morosa and aspera; SHA, Vita Hadriani 11.3). Sabina's dynastic marriage to Hadrian was traditional: she came to Hadrian as a girl of about 14 or 15 years old while he was in his mid-20s, the difference of age being unremarkable in Roman marriages. That she did not share his intellectual interests mattered little for the protocol of a dynastic marriage. Trajan's wife, Plotina, who ensured that Hadrian was adopted by Trajan on his deathbed, was said to have helped arrange the match. The sources allow the Trajanic women a measure of influence: not only Plotina, but Matidia, Sabina's mother, were close to Hadrian and honored with titles and temples. Yet this esteem did not rub off on Sabina.

What were the models for female imperial portraiture for Sabina in the early second century? Sabina's early sculptural portraits adopt the tiered hairstyles worn by private women, rather than the more extreme turreted or diadem styles of her mother and grandmother. ${ }^{10}$ The head on a draped Pudicitia statue from the theater in Vaison-La-Romaine, France, displays the striated band on the forehead from which a crest rises (FIG. 1). ${ }^{11}$ It is marked with incised lines to connote wavy strands, and in the center, the pattern is interrupted to show a double wave. A large nest of braids is wound around the top and back of the head. Although damaged, the head conforms to the conventional portrait features of Sabina: an oval face with prominent cheekbones, angular nose (usually only extant at the bridge), fleshy lips, and long chin. Matched with a nude statue of Hadrian in the Vaison theater, the pair is assumed to have been erected upon the imperial trip to southern France in 121 (or 123?). The Vaison hairstyle is also worn in a portrait of Sabina in the Metropolitan Museum on loan from the Dubroff family (perhaps from Hadrian's villa in Tivoli). ${ }^{12}$

Sabina's early portraits follow those of her peers with the current coiffures, and those of her predecessor with significant revision of effects. The move to the simplicity and elegance of the goddess type seems to occur with the awarding of the title Augusta. Yet the date of this honor and chronology of coin types is not known: dates from 119 through 128 have been proposed, and it is assumed that the diadem signifies the title, Augusta. ${ }^{13}$ Even less well-documented is the claim that Hadrian's Hellenism spurred the stylistic departure of the new portrait type (why in the 130s and not sooner?). One head, in particular, suggests a transition between portraits with modish coiffures and those with divine attributes of classical statuary. An over-lifesized head in the Metropolitan Museum has been identified as Sabina (FIGS. 2-3).${ }^{14}$ Although some have expressed

9. Opper 2008, 200-05.

10. Mattei 2004, 57-67, on portrait heads; for Sabina's imagery on coins, the influence of her forebears ismore pronounced: see Nicolai 2007, 87-107.

11. Wegner 1956, 130-31; Söldner 2010, 224-225; Buccino $2011,373$.

12. Fittschen 1996, 42, 45, fig. 5.
13. Nicolai 2007, 103, note 5, on the lack of certainty for the date of Sabina's assumption of the title Augusta; Alexandridis 2010,212, on the diadem not signifying the role of the Augusta.

14. Metropolitan Museum of Art, inv. n. 22.139.2; Richter, 1948, n. 70, purchased in Rome, Fletcher Fund, 1926, date: ca. 121-128 CE; Carandini, 1969, 149-151, $127 \mathrm{CE}$. 


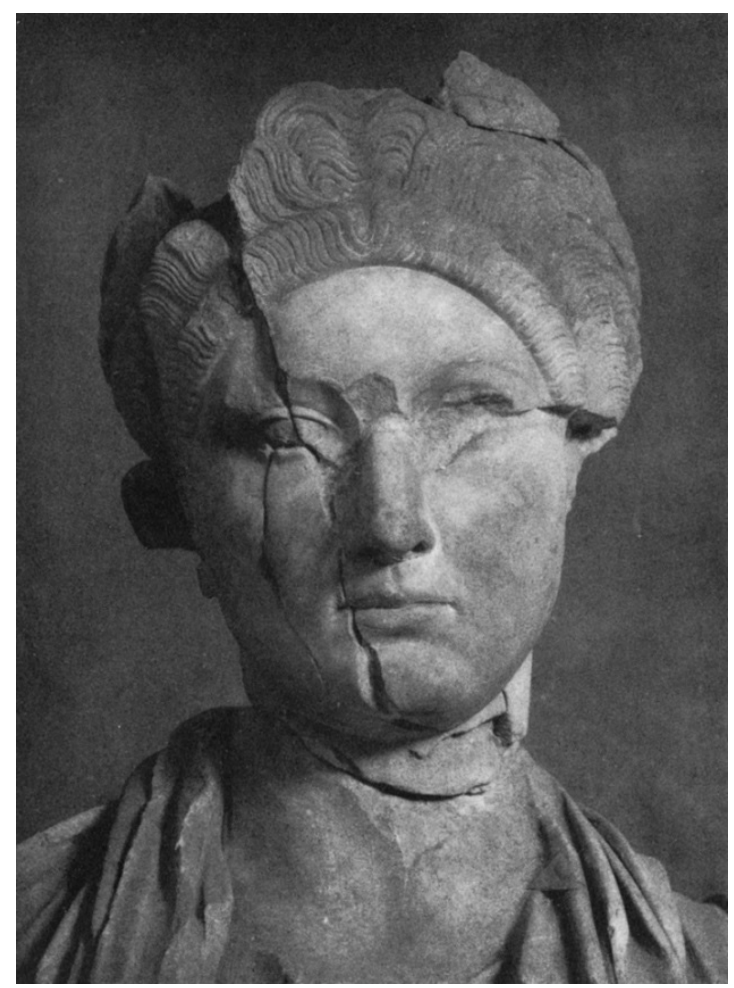

FIG. 1 - Portrait head of Vaison statue (after Wegner, pl. 42a).
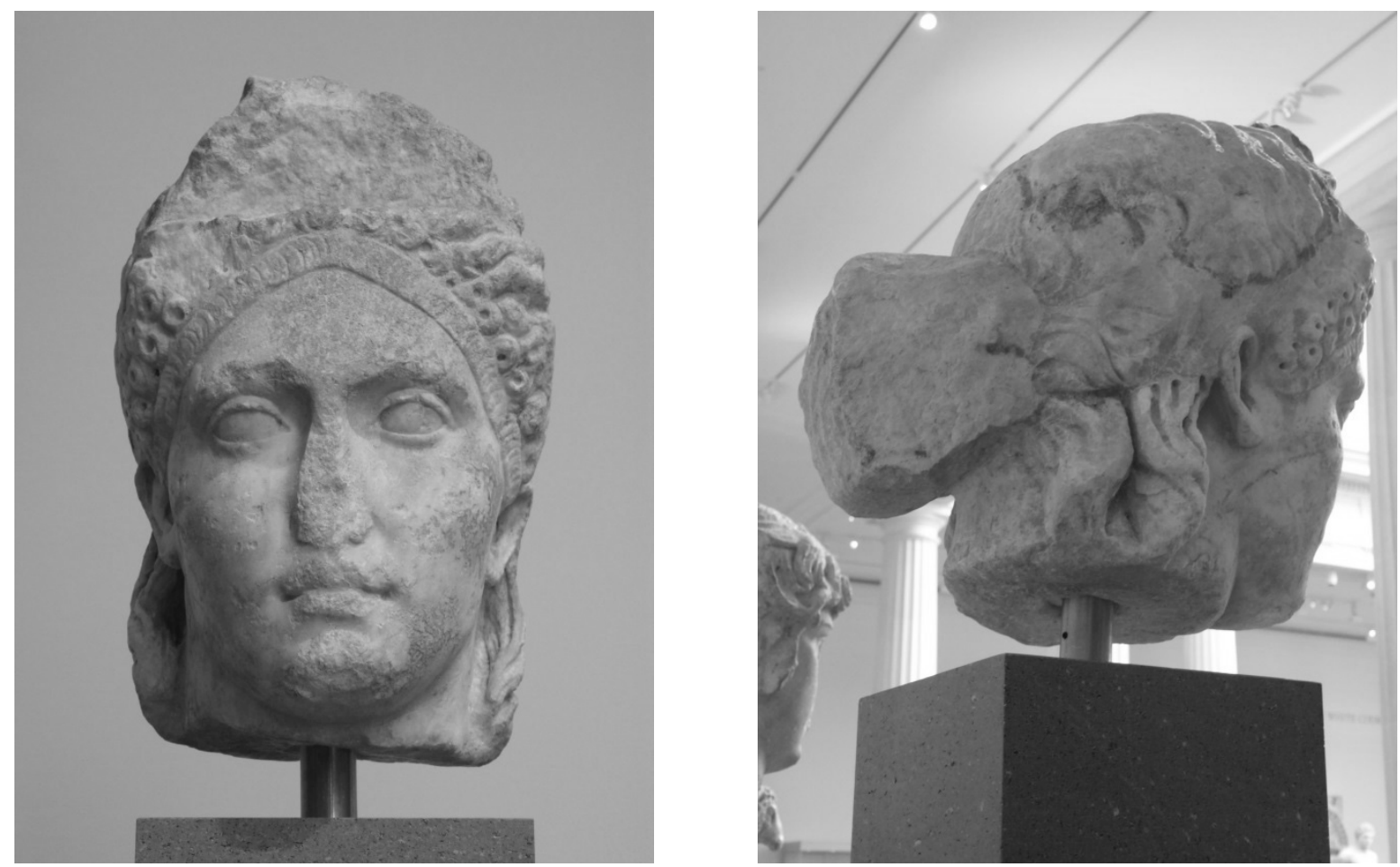

FIGS. 2-3 - Portrait head of Sabina and profile view, the Metropolitan Museum of Art (courtesy of Franc Palaia). 
uncertainty about the identification with Sabina, Carandini observed the oval face, high cheekbones, heavily-lidded eyes, and full lips as portraying Sabina. ${ }^{15}$

Most significant is the coiffure: a peaked pile of ringlets atop a band exemplifying a Trajanic version of the Flavian toupet. The Flavian toupet is appropriate for a woman coming of age about $100 \mathrm{CE}$. Scholars have characterized Sabina's portraits as bearing retrospective coiffures emulating the previous imperial women, although without considering the range of styles current in the private portraits of the period. ${ }^{16}$ A curly pediment above the brow did not necessarily recall Domitia but, rather, appeared regularly as one of the styles current in this period. The hairstyle, however, departs from the Flavian style in the back by creating an entirely different effect. Rather than the tightly braided chignon, long locks are gathered loosely in a blocky knot over the nape of the neck, along with a few locks hanging down over the shoulders (now broken). Both the locks hanging down over the shoulder and the roll in the back evoke Venus as depicted in late as depicted in late Hellenistic statuary. ${ }^{17}$ The Metropolitan Museum head presents an eclectic coiffure: can we see this as a preliminary step in the formation of Sabina's mature portrait style?

It is curious, though, that the Venus locks are reduced to the back and sides, that is, are abbreviated and less visible. The goddesss' attributes were usually made manifest in the front of statuary with varying degrees of nudity of the torso or with cascading locks appearing moistened in a state of dishabille (see the portrait head of Julia Titi with a Venus coiffure in Copenhagen, FIG. 4). The genre of mythological portraits distinguished exemplary women in the guise of Venus with little subtlety in order to praise them, so why render the divine motifs in a minor key? A more typical commemoration of a matron as Venus is seen in the statue from Ostia, often identified as the young Sabina. ${ }^{18}$ It is dated from 113-117 CE as the statue type is thought to commemorate Hadrian's restoration of the Temple of Venus in the Forum of Julius Caesar in Rome. The statue's body conforms to the type of Venus Genetrix with its sheer garment slipping from one shoulder and the gesture of lifting the mantle over the other. The portrait head, however, bears a popular period coiffure with braids wrapped around in a turban. The statue's identification with Sabina is weak (and I have argued elsewhere against this identification ${ }^{19}$ ), but the statue conforms to a standard mythological portrait with body in the form of a deity's established statuary type and the head as in individualized portrait with a period coiffure. That is, the goddess motifs begin at the neck down in this hybrid statue type.

It is, of course, unfortunate that the Metropolitan Museum head is without its body. An overlifesized head requires a substantial figure, most likely a draped one since the extant statues of imperial women demonstrate modesty in their Venus assimilations (although those of private matrons exhibit the full frontal nudity) ${ }^{20}$ It is striking that the highly processed hairstyles trumped the goddess' loose locks. In fact, the rare portrait head of Julia Titi with Venus's dampened locks was not imitated (FIG. 4). ${ }^{21}$ The Metropolitan Museum head bears a hybrid hairstyle, traditional

\footnotetext{
15. Carandini, 1969, n. 21, figs. 59-60, 149-150, here with heaviness of the lower face and prominent cheekbones and eyelids; parallel in a head from Thubursicum Numidarum-Khamissa, in the Museum of Guelma.

16. Fittschen-Zanker, 1983, 10, n. 9, pl. 11.

17. Smtih, 1991, 79-83.
}

18. Germoni, 2007, 130.

19. D'Ambra, 2000, 107, fig. 6.3.

20. D'Ambra, 2016, 65-78.

21. For the portrait head of Julia Titi as Venus in the Ny Carlsberg Glyptotek, see Johansen 1995, n. 11, 4445 . 


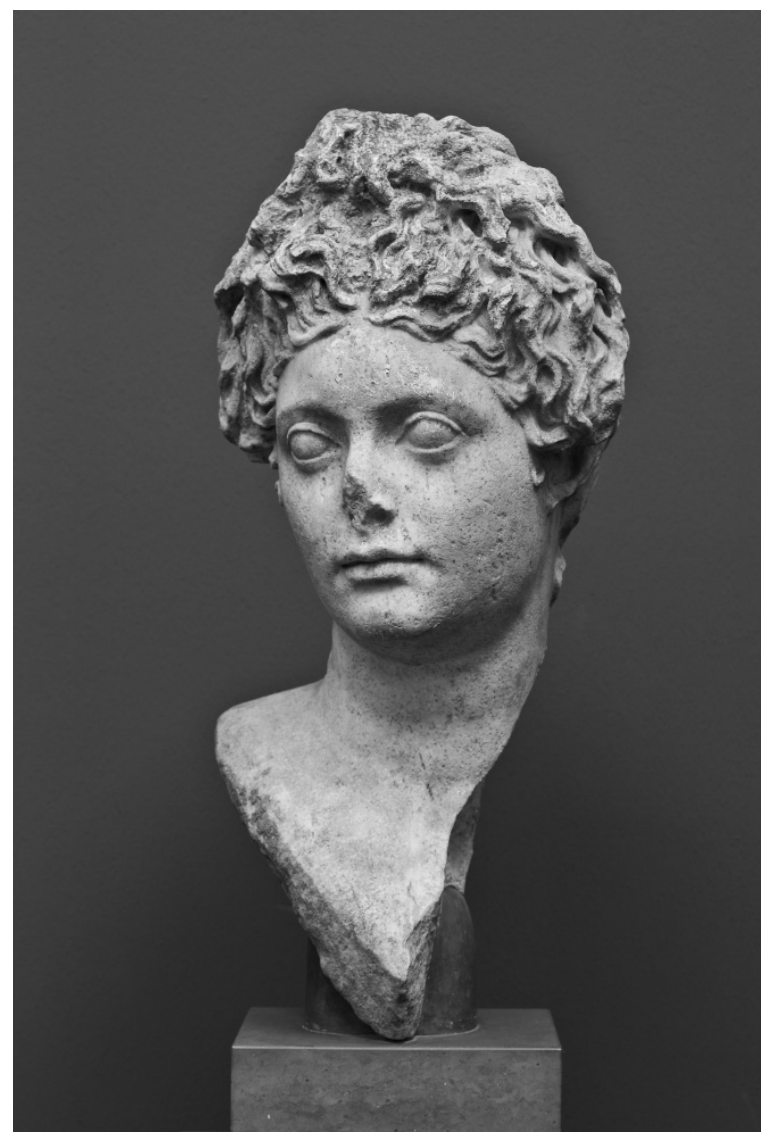

FIG. 4 - Portrait head of Julia Titi in Copenhagen (courtesy of Ny Carlsberg Glyptotek, n. 793).

was not imitated (FIG. 4). ${ }^{21}$ The Metropolitan Museum head bears a hybrid hairstyle, traditional only in the division of its fore and aft. The incongruity of the front and backs of heads resonated with poets: Juvenal (Sat. 6.501) commented on the sight of a toupet-wearing woman who seemed taller from the front, but diminutive from behind as if to appear to be two separate people. This split-screen effect is also reflected in Marital (Ep. 5.49) who took aim at a balding man whose uneven distribution of thinning hair makes him look like he is fragmented into three. The satire only works if hair played a substantial role in social display, and the poet was not the only observer amused by unintended effects of big hair or wayward locks.

Within the Metropolitan Museum head, the juxtaposition of styled hair worn in real life and elements of a coiffure worn on statues of Venus may have been intended to heighten the effects of rarefied beauty. The hair loosely bound in the back formed a coda, a final flourish that complements the orderly precision of ringlets lined up like beads on a string in the front. Roman viewers may have noticed that the head boasts excessive displays of finely finessed hair, rather than the clash between a fashionable hairstyle and a mythological costume that puzzles scholars.

21. For the portrait head of Julia Titi as Venus in the Ny Carlsberg Glyptotek, see Johansen 1995, n. 11, 44-45. 
The subtlety and understatement of the mythological allusion should make us pause. As classical sculpture was thick on the ground in second-century Rome, its motifs and styles were easily adaptable, and Roman sculptors appropriated elements of the traditional repertory, rather than simply copying them. ${ }^{22}$ Selection is evident here in the breaking up of the Venus coiffure to tag on the locks and knob at the back. In other words, statuary of Venus provided the means to accessorize female subjects by fitting discreet motifs into various sculptures with different standards of adornment. In the case of the Metropolitan Museum head, the splitting of the front and back of the hairstyle seems a bold move: the rear locks are a vestige of the goddess' eroticism while the diadem of ringlets up front maintains a respectable demeanor. The dismantling of a classical style suggests an internal order- or reordering - of the beautification process that undermines our immediate perceptions of "borrowings" or "incongruence." The goddess' coiffure was immediately recognizable even in its least visible parts, or why would it replace the plaited nest at the back?

Sabina's early heads represent her as a youthful matron fashioned in the manner of her peers. Does the Metropolitan Museum head suggest a casting around for a distinct look beyond the period style? What emerged was a mediated goddess look. This imperial portrait, as with that of Julia Titi with the Venus locks, inspired no imitations from their peers or the women of Rome. It stood apart from the mainstream of female portraiture because the more traditional coiffures (in fore and aft) satisfied the conflicting requirements that hair both modestly cover the head and evoke well-crafted or sumptuous forms of regalia. The Metropolitan Museum head suggests an earlier turn to ideal sculptural forms in the development of Sabina's mature portrait styles. The dominance of the period coiffure of private women in this hybrid work documents the dependence of female imperial portraiture on the imagery of Roman women.

Eve D'Ambra

Vassar College, New York

evdambra@vassar.edu

22. Marvin 2008, 168-217. 


\section{BIBLIOGRAPHY}

Alexandridis, A. 2010: "The Other Side of the Coin: The Women of the Flavian Imperial Family," in Tradition und Erneuerung: Mediale Strategien in der Zeit der Flavier, eds. N. Kramer and C. Reitz, Berlin and New York, 191237.

Boatwright, M. 1991: "The Imperial Women of the Early Second Century A.C.," AJPh 112.4, 513-540.

Buccino, L. 2011: "Morbidi capelli e acconciature sempre diverse," in Ritratti, le tante facce del potere, eds. E. La Rocca, C. Parisi Presicce and A. Lo Monaco, Rome, 361383.

Buccino, L. 2012: in L'Età dell'Equilibrio, 98- 180 d.C., eds. E. La Rocca, C. Parisi Presicce and A. Lo Monaco, Rome, 271.

Carandini, A. 1969: Vibia Sabina, Firenze.

D'Ambra, E. 2000: "Nudity and Adornment in Female Portrait Sculpture of the Second Century AD," in I Claudia II: Women in Roman Art and Society, eds. D. Kleiner and S. Matheson, New Haven, 101-114.

D'Ambra, E. 2013: "Mode and Model in the Flavian Female Portrait," AJA 117.4, 511-525.

D'Ambra, E. 2016: "The Importance of Being Venus," in Icon, Cult and Context: Sacred Places and Objects in the Classical World, eds. M. Heyn and A. Steinsapir, Los Angeles, 65-78.

Fejfer, J. 2008: Roman Portraits in Context, Berlin and New York.

Fittschen, K. 1996: "Courtly Portraits of Women in the Era of Adoptive Emperors (AD 98-180) and their Reception in
Roman Society," in I Claudia: Women in Ancient Rome, eds. D. Kleiner and S. Matheson, New Haven, 42-52.

Fittschen, K. and Zanker, P. 1983: Katalog der römischen Porträts in den Capitolinischen Museen und den anderen kommunalen Sammlungen der Stadt Rom, v. 3, Mainz am Rhein.

Germoni, P. 2007: in Vibia Sabina: da Augusta a diva, eds. B. Adembri and R.M. Nicolai, Milan, 130.

Johansen, F. 1995: Roman Portraits II: Ny Carlsberg Glyptotek, Copenhagen.

Marvin, M. 2008: The Language of the Muses, Los Angeles.

Mattei, M. 2004: "Iconografia di Augustae e di privatae tra la fine del I e gli inizi del III secolo d.C. Il ritratto come messaggio," in Adriano: le memorie al femminile, ed. A. M. Reggiani, Milan, 57-67.

Nicolai, R. M. 2007: "Le monete emesse a nome di Sabina," in Vibia Sabina: da Augusta a diva, eds. B. Adembri and R.M. Nicolai, Milan, 87-107.

Opper, T. 2008: Hadrian: Empire and Conflict, Cambridge, Mass.

Richter, G. 1948: Roman Portraits, New York.

Söldner, M. 2010: “An der Seite des Kaisers: Sabina,” in Die Geschichte der antiken Bildhauerkunst, ed. P. Bol, Mainz, 224-228.

Smith, R. 1991: Hellenistic Sculpture, New York.

Wegner, M. 1956: Das römische Herrscherbild, v. II.3: Hadrian, Berlin.

Wood, S. 2015: "Women in Action: A Statue of Matidia Minor and its Contexts", AJA 119.2, 233-259. 